\title{
Vanina Sumrova, Nowe feminatywa w języku bułgarskim, Wydawnictwo Bułgarskiej Akademii Nauk „Prof. Marin Drinov”, Sofia 2018, sS. $196^{1}$
}

\begin{abstract}
Streszczenie
Recenzja dotyczy wydanej niedawno w Bułgarii książki Vaniny Sumrovej. Prowadzone przez autorkę badania są pierwszym niezależnym i kompletnym leksykalno-semantycznym zestawieniem grup neologizmów w języku bułgarskim, odnoszących się do nazw kobiet, ich działalności i ról społecznych. Są to głównie określenia, które pojawiły się w języku bułgarskim w ostatnim ćwierćwieczu, w sumie 1400 przykładów. Zgromadzony przez badaczkę materiał analizowany jest na kilku płaszczyznach: morfologicznej, semantycznej, stylistycznej, kodyfikacyjnej, socjolingwistycznej, kulturowej, społecznej, leksykograficznej i dotyczącej możliwości przyszłego rozwoju.
\end{abstract}

Słowa kluczowe: feminatywy, język bułgarski, neologizmy, neosemantyzm

W ostatnich latach w Bułgarii drukiem ukazało się wiele artykułów i omówień poświęconych tworzeniu w języku bułgarskim współczesnych nazw kobiecych (m.in. nazw zawodów, tytułów, imion). Wiele z tych prac miało charakter dydaktyczny, inne krytyczny, jeszcze inne konfrontowały współczesne, żeńskie, bułgarskie nazwy z ich odpowiednikami w innych, nowożytnych językach. Trudno byłoby w tym miejscu przedstawić wszystkie publikacje, niemniej należy wymienić choćby kilku autorów, których dorobek na trwałe

\footnotetext{
1 Ванина Сумрова, Новите феминални названия в българския език, Издателство на БАН „Проф. Марин Дринов“", София 2018, сс. 196.
} 
wszedł do obiegu naukowego i jest często cytowany. Mam tu na myśli książki i artykuły dotyczące języka bułgarskiego: N. Aleksievej (2006, 2007), J. Baltovej (2012), D. Blagoevej (2013b i kolejne), V. Bondzolovej (2007), C. Georgievej (2013), S. Kolkovskiej (2012), V. Murdarova (2010), E. Pernishkiej (2010), V. Radevej (2017), V. Zidarovej (2014), a także teksty konfrontujące język bułgarski z innymi językami nowożytnymi: C. Avramovej (2003, 2006), D. Blagoevej (2013a), a ostatnio M. Koshkovej i J. Satoły-Staśkowiak (2017).

Do tego grona moim zdaniem należy zaliczyć również V. Sumrovą, uczoną z Instytutu Języka Bułgarskiego, Bułgarskiej Akademii Nauk w Sofii z jej pierwszym, kompletnym studium obejmującym ponad 1400 nowych (powstałych w ostatnim ćwierćwieczu) feminatywów w języku bułgarskim².

Przygotowując rozprawę, V. Sumrova przeprowadziła gruntowną kwerendę. Znaczna część materiału wywodzi się ze słowników: Rechnik na novite dumi v balgarskia ezik (ot kraya na XX i parvoto desetiletie na XXI v. ${ }^{3}$ [Речник на новите думи в българския език (от края на ХX и пьрвото десетилетие на XXI в.] autorstwa E. Pernishkej, D. Blagoevej i S. Kolkovskiej (Sofia 2010, 515 stron) - najbogatszego w materiał istniejącego słownika neologizmów bułgarskich, a także słownika zatytułowanego Rechnik na novite dumi i znachenia $v$ balgarskia ezik ${ }^{4}$ (Речник на новите думи и значения в българския език) autorstwa tych samych autorek (Sofia 2003, 309 stron). Ekscerpowany materiał wyłoniony został również z licznych prac leksykograficznych podejmujących fragmentarycznie omawianą problematykę, a także z losowo wybranych numerów najpopularniejszych w Bułgarii gazet, takich jak „24 chasa” (,24 часа”), „Duma” („Дума), „Demokratsia” („Демокрация”), „Novinar” („Новинар”), „Standard” („Стандарт”), „Dneven Trud” („Дневен Труд”), „Noshten Trud” („Нощен Труд”), a także z internetu (fora internetowe, czaty, blogi itd.).

Klasyczne badania terenowe zastąpione zostały pracami z przeglądarkami internetowymi, a uzyskany w całości materiał badawczy przedstawia autorka jako wnikliwy i intersujący zbiór jednostek języka wraz z różnorodną i złożoną ich analizą (struktura, semantyka, funkcjonowanie i osobliwości), tworząc konsekwentny wywód naukowy, potwierdzony licznymi przykładami. Autorka drobiazgowo i ciekawie opisuje obserwacje i sugeruje wnioski o aktualnym stanie feminatywów w języku bułgarskim, a także o istotnych powodach ich powstawania, do których zalicza ważne w Bułgarii i na świecie zmiany obejmujące: sferę społeczno-polityczną, ekonomiczną, techniczną i technologiczną, wojskową, kulturalną, naukową, ideologiczną, religijną i przemiany dotyczące systemu wartości.

${ }^{2}$ W roku wydania przez Vaninę Sumrovą monografii - roku 2018 - w Polsce obchodzono stulecie uzyskania praw wyborczych kobiet. Najpewniej w związku z tym obserwowano szczególne, inne niż w poprzednich latach, zainteresowanie feminatywami. Rozmowy na ten temat inicjowały nawet osoby i grupy, które nigdy dotychczas nie zajmowały się tematem. Z powodów społecznych, politycznych i ekonomicznych podobne zainteresowanie obserwowane jest w Bułgarii, choć tam kobiety prawo wyborcze otrzymały dopiero w 1944 roku.

3 Dalej: РНДБЕ.

${ }^{4}$ Dalej: РНДЗБЕ. 
Z formalnego punktu widzenia prezentowane przez V. Sumrovą „nowe słowa" należą do różnych części mowy (są nimi rzeczowniki, przymiotniki, czasowniki i ich połączenia). Niektóre z nowo powstałych w języku bułgarskim jednostek mają charakter wyłącznie nominatywny, podczas gdy inne - ekspresyjny.

Autorka omawia w książce „,rewolucję medialną” (Znepolski, 1997) i obecną tam inwazję kolokwializmu, która odegrała znaczącą rolę w procesie odnowy/budowy nowego bułgarskiego słownictwa. Zauważa również za V. Tabakovą (1995: 81), że w Europie, także w Bułgarii, „kobiety stanowią większość ludności kraju” (s. 9), dlatego ważne jest, aby prześledzić językoznawcze procesy i odzwierciedlić ich działania konkretnymi przykładami w języku bułgarskim.

Metodologia opisu. W badaniu V. Sumrova wykorzystuje tradycyjną metodę opisu lingwistycznego opartą na obserwacji i analizie, przeprowadzoną za pomocą strukturalnego semantycznego, funkcjonalno-pragmatycznego, socjolingwistycznego, społeczno-kulturowego i perspektywicznego podejścia. Z jednej strony jest to zgodne z podejściami w badaniach porównawczych, a z drugiej strony prezentowane nazwy analizowane są z różnych aspektów - słowotwórczego, semantycznego, stylistycznego, normatywnego, socjolingwistycznego, społeczno-kulturowego, leksykograficznego, prognostycznego. Daje to monografii złożony charakter i odróżnia ją od istniejących badań feminatywów w języku bułgarskim i innych językach (na przykład w języku rosyjskim).

Recenzowana praca liczy 196 stron i składa się ze wstępu, sześciu rozdziałów, podsumowania, spisu użytych w pracy skrótów, bibliografii oraz spisu leksykalnych i semantycznych neologizmów feminatywnych.

We wstępie (s. 7-24) czytelnikowi przedstawiona jest ogólna charakterystyka prezentowanego w pracy zagadnienia, tendencje feminatywne po 1989 roku, istotne dla pracy naukowe studia leksykalno-semantyczne, cel pracy, obszar badań, obrane metody badań nowych nazw żeńskich. Ważną część wstępu stanowi omówienie aparatu terminologicznego i kryteria użycia poszczególnych terminów naukowych. Za wyjątkowo istotne uważam rozróżnienie neologizmów i okazjonalizmów. Bez tego nie można by było prowadzić rozważań nad nowymi nazwami kobiecymi. Tutaj mieści się także część opisująca źródła prezentowanego na stronach monografii materiału językowego.

W rozdziale I (s. 25-65) pod tytułem Techniki nominacyjne autorka przybliża współczesne techniki tworzenia neologizmów (słowotwórstwo, neosemantyzacja, zapożyczenia), ilustrując je odpowiednią liczbą przykładów i odniesień do literatury naukowej. Owe sposoby powstawania nowych słów prezentowane są w licznych grupach i podgrupach (opierających się na sufiksacji, kompozycji, uniwerbalizacji itd.), wszystko po to, by nawet mało wprawny czytelnik mógł zapoznać się z bieżącymi procesami feminatywnymi w języku bułgarskim i wyrobić sobie zdanie na ich temat. Dla badacza innych języków materiał skutecznie wspiera badania konfrontatywne, pozwalając na porównania z innymi językami (na przykład słowiańskimi).

5 Autorka wzięła pod uwagę feminatywa, które weszły do systemu języka bułgarskiego, posiadają liczne dowody na istnienie, odróżniając tym samym okazjonalizmy, które nie mają statusu opisywanych przez nią neologizmów. 
W rozdziale II (s. 66-80) zatytułowanym Klasyfikacja V. Sumrova ocenia opisywane słownictwo według, istotnych jej zdaniem, kryteriów badawczych: słowotwórstwa, semantyki [фараонка (на финансова пирамида), наставничка 'треньорка', шаманка 'политичка, общественичка, която ръководи, насочва някого или нещо', каналджийка 'жена каналджия'], stylistyki (аверка, рокаджийка, блу сар ка, чалгаджийка, бензинджийка, аграрничка, аграрка, агит каджийка, халтураджийка, папарачка, естрадничка, фа раонка, мутреса, свежарка, небрежсарка, костюмарка, въз духарка, анонимничка, алтернативничка), norm literackich (министърка, прокурорка, съдийка, деканка, войничка, лейтенантка, офищерка) i perspektywy historycznej, którą uważa za najważniejszą w procesie definiowania nowego słownictwa. Tutaj następuje konieczny dla prowadzonych badań i zestawianych przykładów podział na leksykę nową i okazjonalną. Do okazjonalizmów (mocno ograniczonych kontekstem, czasem i sytuacją komunikacyjną) zalicza autorka następujące przykłady: плажорка, моржка, адреналинка, рачка, айсикютка, донжуанка, пе дерасткиня, талантливка, перхидролка, небрежарка, без хаберничка, баладжийка, прекрасничка, ненагледница, недостьпница, разкочка, случайка, претенциозка, меркан тилка, мъжемелачка.

W rozdziale III (s. 81-124) zatytułowanym Maskulinizacja rzeczowników badaczka opisuje bułgarską praktykę językową dotyczącą maskulinizacji bułgarskich rzeczowników, obserwowaną na przestrzeni ostatnich osiemdziesięciu lat. Powołuje się V. Sumrova na liczną bibliografię oraz przyczyny i zjawiska charakterystyczne dla tego procesu. Podejmuje udaną próbę wyjaśnienia powodów rozpoczęcia procesu maskulinizacji, jego trwania, opisuje także intersujący fakt samonazywania się kobiet oraz niewygodę językową niedogodności związane z maskulinizacją lub spowodowane przez nią trudności i błędy językowe [Министьрьт на земеделието и горите Десислава Танева и заместниците му (примерът е от архива на Службата за езикови справки в ИБЕ при БАН); Съдии от СГС поискаха оставката на председателя Владимира Янева и заместниците му; Моят психотерапевт казва, че [...] и затова спрях да я посещавам] (por. Sumrova, 2018: 104).

Ważny temat podejmowany przez autorkę w tym rozdziale to maskulinizacja a równość płci. Przywołuje tu V. Sumrova zdania innych badaczy, zilustrowane przykładami. Konkluzją są stwierdzenia, że „maskulinizacja jest złożonym zjawiskiem deterministycznym" (por. Sumrova, 2018: 114), a także odautorskie informacje, że opis maskulinizacji zależy od punktu i rodzaju odniesienia, tradycji językowej i wielu innych czynników: semantycznego, gramatycznego, stylistycznego, socjolingwistycznego oraz - według niektórych autorów - także fonetycznego i słowotwórczego. Temat dopełniają wyniki przeprowadzonej przez autorkę na potrzeby monografii ankiety dotyczącej procesów maskulinizacji, która to (ankieta) ma za zadanie sprawdzić, czy maskulinizacja występuje w komunikacji ustnej i czy stwarza w mowie jakiekolwiek problemy. Omawiana ankieta nie ma charakteru reprezentatywnego (z powodu braku reprezentatywnej próby), zatem fakty interpretowano raczej z językowego niż socjolingwistycznego punktu widzenia.

W rozdziale IV (s. 125-136) zatytułowanym Osobliwości neofeminatywów grupuje V. Sumrova neofeminatywa ze względu na: 
1. Cechy paradygmatyczne (synonimy, homonimy, antonimy i paronimy). Największa część z nich to synonimy (jak korelaty form męskich, np. форумка, форумджийка і форумистка - od форумец, форумджия і форумист, телевизионистка і телевизионерка - od телевизионист і телевизионер, атакаджийка і атакистка - od атакаджия і атакист, меверейка і меверистка - od мевереец і меверист, запалянка і запалянковка - od запалянко і запалянковеи, чалгаджийка і чалгарка - od чалгаджия і чалгар i wiele innych), mniejsza homonimy (пицарка posiadająca dwa znaczenia: 'kucharka, specjalistka od przygotowywania pizzy' oraz 'kobieta, która bardzo lubi pizzę') najmniejsza grupa to antonimy (антиамериканка - проамериканка, антиевропейка - проевропейка і съветофилка - съветофобка, американофилка - американофобка, еврофилка - еврофобка, ислямофилка - ислямофобка, хомофилка-хомофобка), a paronimia występuje tylko w dwóch leksemach (плейбойка і плебейка).

2. Cechy gramatyczne - ilustrowane przykładami użycia leksemu dla określenia kobiety lub mężczyzny, np. костюмарка, небрежарка, свежарка и комунарка. „Момчето изглежда голяма свежарка; Гаро не е ли найголямата свежарка в шоуто!; Батето верно си е абсолютна свежарка; Беше кална, долнопробна комунарка! (por. Sumrova, 2018: 135).

3. Cechy semantyczne (omawiane już na innych stronach monografii) ilustrowane przykładem neosemantyzmu пиацаджийка (w znaczeniu 'prostytutka').

W rozdziale V (s. 125-143) pod tytułem Nowe feminatywa $w$ aspekcie kulturowo-językowym V. Sumrova omawia współczesny wizerunek kobiet, odzwierciedlany w feminatywach. Syntetycznie przedstawia i omawia obszary, w których określona nazwa kobiety najczęściej znajduje swój wyraz. Nazwy kobiet skoncentrowane na wykonywanym przez nie zawodzie lub okołozawodowej działalności są najliczniejszą grupą nowego słownictwa (na przykład tworzonego dzięki sufiksom -манк(a) i -холичк(a) lub с маниачка, o którym mowa w monografii (por. ароматоманка, блогоманка, графитоманка, мар команка, меломанка, телеманка, хероиноманка, сексоманка, ерото ман ка; работохоличка, интернетохоличка, нетохоличка, пазарохоличка, шопингхоличка, шопохоличка, сексохоличка, артхоличка, книгохоличка, кафехоличка) (por. Sumrova, 2018: 138).

Inne wyekscerpowane przez autorkę neofeminatywa zwracają uwagę czytelnika na przedstawicielki określonych warstw społecznych. Słowa хайлайфаджийка, хайлафка, хайдама, хайжена mówią o zbyt dużym zainteresowaniu społeczeństwa kobietą z wyższych sfer, życia politycznego, showbiznesu i całej popkultury. O zauważaniu obecności kobiet reprezentujących mniejszości świadczą następujące leksemy: ромка, мургава, мургавелка, смугла. Natomiast wiele nowych leksemów określa kobiety żyjące z ważnymi lub bogatymi mężczyznami, którzy mają decydującą rolę w zajmowanej przez nie pozycji społecznej, na przykład: президентма, премиерша, министьрпредседателша, де путатша, дипломатша, сенаторша, канилерша, albo ich dorastające córki: тийнейджърка, тийнка, юношка, пуберка, пубертетка.

Znaczna część przywoływanych przez V. Sumrovą przykładów dotyczy wyglądu, mody, zainteresowań, relacji z innymi: аутсайдерка i postrzegania kobiet w konkretnej grupie. Część z nich ma wartość umniejszającą i obraźliwą: перхидролка, силиконка. Są 
jednak takie, które odwrotnie - dzięki cechom osobowości, umiejętnościom jednoznacznie przypisują wartość: перфекционистка, свежарка, рамбовка. Podsumowanie rozdziału stanowi dość górnolotna konkluzja autorki, która stwierdza, że nowe feminatywa pokazują, że „bohaterami naszych czasów” są nie tylko mężczyźni, ale także kobiety. Obraz współczesnej kobiety prezentowany jest współcześnie przez jej działalność zawodową, orientację polityczną, religijną lub seksualną, jej zainteresowania i uzależnienia. Nazwy kobiet odzwierciedlają także różne ich cechy, osobliwości i stosunek społeczeństwa do nich oraz do grup, które reprezentują. Przedstawiają zdaniem V. Sumrovej radykalnie inny dzisiaj (w porównaniu z przeszłością) obraz kobiety. Obraz ten, choć nie tak wszechstronny i dogłębny, wyłania się również z innych, znacznie mniej rozbudowanych ostatnich prac językoznawczych na ten temat.

W rozdziale VI zatytułowanym Aspekty leksykograficznej prezentacji feminatywów (s. 144-148) autorka omawia dawne i współczesne problemy dotyczące prezentacji w słownikach i leksykonach nowych feminatywów. Wśród wielu spostrzeżeń warto zauważyć zaakcentowane przez V. Sumrovą minione i nieistniejące już spory dotyczące prezentacji feminatywów (jako osobnych haseł) obok istniejących nazw męskich, a także możliwości udokumentowania częstotliwości użycia niektórych nowych feminatywów, po to by mogły zostać włączone do słowników języka bułgarskiego i odróżnione od niebranych pod uwagę okazjonalizmów. Ogromną rolę odgrywają tu słusznie zauważone korpusy językowe, które dzięki opracowanym metadanym przekazują informacje o źródle ekscerpcji danej jednostki i częstotliwości jej użycia.

Prezentowane w Podsumowaniu wnioski autorskie, podobnie jak inne współczesne badania zajmujących się zagadnieniem językoznawców, świadczą o tym, że współczesny język bułgarski nie ma formalnych ograniczeń semantycznych, fonetycznych, słowotwórczych czy stylistycznych w tworzeniu nowych feminatywów i z łatwością może zapełniać potencjalnie puste jeszcze miejsca.

Autorka w badaniach nad neofeminatywami starannie prezentuje stanowiska licznych językoznawców. Świadomie i słusznie z niektórymi polemizuje, stwierdzając, że nie warto, jak sugerują niektórzy językoznawcy, traktować neologizmów jako niepewnych jednostek języka ani obniżać ze względu na ich potoczność ich wartości leksykograficznej. Kwestią czasu zdaniem V. Sumrovej jest zakorzenienie w systemie języka i traktowanie wielu prezentowanych w monografii przykładów jako neutralnych stylistycznie. Tak wyartykułowane przez V. Sumrovą i przyjęte na początku rozprawy założenia teoretyczno-metodologiczne skutkują według mnie ciekawym materiałem i precyzyjnym opisem ekscerpowanych jednostek.

Recenzowana monografia jest pierwszym - powstałym ponad ćwierć wieku po 1989 roku - i kompletnym studium zawierającym nowe feminatywa w języku bułgarskim. Ilustruje i obejmuje egzemplifikacją ponad 1400 przykładów, które pozwoliły ukazać szerokie spektrum zjawisk dotyczących jednostek feminatywnych. Rzetelny sposób prezentacji materiału, a także przejrzysty język stanowią dodatkowy walor monografii, która z pewnością przedstawia cenne naukowe źródło informacji nie tylko dla językoznawców - bułgarystów i slawistów, ale również dla wszystkich zainteresowa- 
nych poprawną komunikacją językową Bułgarów (studentów, dziennikarzy, pasjonatów i zwykłych użytkowników języka). To także dobry materiał dla socjologów i badaczy współczesnego feminizmu.

\section{Bibliografia}

Аврамова Цв. (2003), Словообразувателни тенденции при съществителните имена в българския и чешкия език в края на XX век, София.

Аврамова Цв. (2006), За конкуренцията в суфиксалното субстантивно словообразуване на българския и чешкия език в края на ХХ век, [в:] Националният език в условията на чужди влияния и глобализация, София.

Алексиева Н. (2006), Активната роля на нацционалния език при чуждо лексикално влияние, [в:] Националният език в условията на чужди влияния и глобализация, София.

Алексиева Н. (2007), Лексикалното заемане - специфичен словообразувателен модел, [в:] За човека и езика, София.

Балтова Ю. (2012), За езиковата интерпретация и правописа на някои неологизми в съвременния български книжовен език, [в:] Магията на думите, София.

Благоева Д. (2013а), Динамика в конщептосферата „Общество и политика“ в края на ХХ и началото на XXI век, [в:] Проблеми на неологията в славянските езици, София.

Благоева Д. (2013б), Подходи при изучаване на новата лексика, [в:] 50 години - врата към образованието и прозореи към света, София.

Бонджолова В. (2007), Феминативите - между неологичното и оказионалното, [в:] Трудове на Великотърновския университет „Св. св. Кирил и Методий”, т. 34 (за 2004), кн. 2, Езикознание.

Георгиева Ц. (2013), Иновационни процеси в българската именна префиксаџия, София.

Колковска С. (2012), Лексикални неологизми в българския език, възникнали чрез отсичане, [в:] Čěstina v pohledu synchronním a diachronním. Stoleté kořenyÚstavu pro jazyk český, Praha.

Košková M., Satoła-Staśkowiak J. (2017), Všeobecný mužský rod a maskulinizácia v slovenskom, pol'skom a bulharskom jazykovom prostredí, „Slavica Slovaca”, 1.

Мурдаров В. (2010), За националното своеобразие на езика ни, [в:] Български език, Приложение.

Пернишка Е. (2010), Съвременните български неологизми и езиковата система, [в:] Лексикографията в европейското културно пространство, Велико Търново.

Радева В. (2017), Българска лексикология и лексикография, София.

Речник на новите думи в българския език (от края на ХХ и първото десетилетие на $X X I$ в.) (2010), Наука и изкуство, София.

Речник на новите думи и значения в българския език (2003), Наука и изкуство, София.

Табакова В. (1995), Жените в медиите и демистификацията на „триединния ролеви модел”, [в:] Журналистиката в тоталитарното и посттоталитарното общество, София. 
Зидарова В. (2014), Словообразувателни похвати при оказионализмите в съвременната българска преса, [в:] Славис ти ката и българистиката днес: въпроси, идеи, посоки, Благоевград.

Знеполски И. (1997), Новата преса и преходът. Трудното преструктуриране на четвъртата власт, София.

\section{Bibliografia po transkrypcji}

Avramova Ts. (2003), Slovoobrazuvatelni tendentsii pri sashtestvitelnite imena v balgarskia icheshkia ezik $v$ balgarskia $i$ cheshkia ezik v kraya na XX vek, Sofia.

Avramova Ts. (2006), Za konkurentsiyata v sufiksalnoto substantivno slovoobrazuvane na balgarskia i cheshkiyaezik v kraya na na XX vek, [w:] Natsionalniyat ezik v usloviyata na chuzhdi vliyania i globalizatsia, Sofia.

Aleksieva N. (2006), Aktivnata rolya na natsionalnia ezik pri chuzhdo leksikalno vliyanie. Natsionalniyat ezik pri chuzhdo leksikalno vliyanie, [w:] Natsionalniyat ezik v usloviyata na chuzhdivliyania i globalizatsia, Sofia.

Aleksieva N. (2007), Leksikalnoto zaemane - spetsifichen slovoobrazuvatelen model, [w:] Za choveka i ezika, Sofia.

Baltova Yu. (2012), Za ezikovata interpretatsia i pravopisa na nyakoi neologizmi vsavremennia balgarski knizhoven ezik, [w:] Magiyata na dumite, Sofia.

Blagoeva D. (2013a), Dinamika v kontseptosferata ,Obshtestvo i politika“ v kraya na XX i nachaloto na XXI vek, [w:] Problemi na neologiyata v slavyanskite ezitsi, Sofia.

Blagoeva D. (2013b), Podhodi pri izuchavane na novata leksika, [w:] 50 godini-vrata kam obrazovanieto i prozorets kam sveta, Sofia.

Bondzholova V. (2007), Feminativite - mezhdu neologichnoto i okazionalnoto, [w:] Trudove na Velikotarnovskia universitet „Sv.sv. Kiril i Metodiy”, t. 34 (za 2004), kn. 2, Ezikoznanie.

Georgieva Ts. (2013), Inovatsionni protsesi v balgarskata imenna prefiksatsia, Sofia.

Kolkovska S. (2012), Leksikalni neologizmi v balgarskia ezik, vazniknali chrez otsichane, [w:] Čeština v pohledu synchronním a diachronním. Stoleté kořenyÚstavu pro jazyk český, Praha.

Košková M., Satoła-Staśkowiak J. (2017), Všeobecný mužský rod a maskulinizácia v slovenskom, pol'skom a bulharskom jazykovom prostredi, „Slavica Slovaca”, 1.

Murdarov V. (2010), Za natsionalnoto svoeobrazie na ezika ni, [w:] Balgarski ezik, Prilozhenie.

Pernishka E. (2010), Savremennite balgarski neologizmi i ezikovata sistema, [w:] Leksikografiyata v evropeyskoto kulturnoprostranstvo, Veliko Tarnovo.

Radeva V. (2017), Balgarska leksikologia i leksikografia, Sofia.

Rechnik na novite dumi v balgarskia ezik (ot kraya na XX i parvoto desetiletie na XXI v.) (2010), Nauka i izkustvo, Sofia.

Rechnik na novite dumi i znachenia v balgarskia ezik (2003), Nauka i izkustvo, Sofia.

Tabakova V. (1995), Zhenite v mediite i demistifikatsiyata na ,triedinnia rolevi model”, [w:] Zhurnalistikata $v$ totalitarnoto i posttotalitarnoto obshtestvo, Sofia. 
Zidarova V. (2014), Slovoobrazuvatelni pohvati pri okazionalizmite v savremennata balgarska presa, [w:] Slavistikata i balgaristikata dnes: vaprosi, idei, posoki, Blagoevgrad.

Znepolski I. (1997), Novata presa i prehodat. Trudnoto prestrukturirane na chetvartata vlast, Sofia.

\begin{abstract}
Vanina Ivanova Sumrova, New Terms Denoting Women in the Bulgarian Language, Prof. Marin Drinov Publishing House of Bulgarian Academy of Sciences, Sofia 2018, $196 \mathrm{p}$.

This investigation of Vanina Ivanova Sumrova is the first independent and complete study of a lexico-semantic group of neologisms in the Bulgarian language: the new terms denoting women that have appeared throughout the quarter century that has passed since 1989 . The terms covered are more than 1.400 ; single-word terms as well as open or closed two-element compounds (of the type biznes sekretarka or bg mama), part of them until now unattested in studies or dictionaries. The terms are analysed from several points of view: morphology, semantics, stylistics, codification, sociolinguistics, social culturology, lexicography, and possibilities for future development; all contributing to the multifaceted character of the study.
\end{abstract}

Keywords: feminatives, Bulgarian language, neologisms, neosemantisms 